Royal Netherlands Institute for Sea Research

This is a postprint of:

Walles, B., Smaal, A.C., Herman, P.M.J., \& Ysebaert, T. (2016). Niche dimension differs among life-history stages of Pacific oysters in intertidal environments. Marine Ecology Progress Series, 562, 113-122.

Published version: dx.doi.org/10.3354/meps11961

Link NIOZ Repository: $w$ ww.vliz.be/nl/imis?module=ref\&refid=283875

[Article begins on next page]

The NIOZ Repository gives free access to the digital collection of the work of the Royal Netherlands Institute for Sea Research. This archive is managed according to the principles of the Open Access Movement, and the Open Archive Initiative. Each publication should be cited to its original source - please use the reference as presented.

When using parts of, or whole publications in your own work, permission from the author(s) or copyright holder(s) is always needed. 


\title{
Niche dimension differs among life-history stages of Pacific oysters in intertidal environments
}

\author{
Brenda Walles ${ }^{1,2,3 *}$, Aad C. Smaal ${ }^{1,2}$, Peter M.J. Herman ${ }^{3}$ and Tom Ysebaert ${ }^{1,3}$ \\ ${ }^{1}$ Wageningen University \& Research, Wageningen Marine Research, PO Box 77, 4400 AB Yerseke, The \\ Netherlands \\ ${ }^{2}$ Aquaculture and Fisheries Group, Wageningen University and Research, PO Box 338, 6700 AH Wageningen, The \\ Netherlands \\ ${ }^{3}$ NIOZ Yerseke, Royal Netherlands Institute for Sea Research and Utrecht University, PO Box 140, 4400 AC \\ Yerseke, The Netherlands \\ *corresponding author: brenda.walles@ nioz.nl
}

\begin{abstract}
Structure building, autogenic ecosystem engineers are worldwide recognized as potential tools for coastal protection, which depends on long-term sustainability and persistence of their structures. For reef-building oysters, reefs are maintained through accumulation of shell material, which depends on recruitment and growth and which provides substrate for new generations. Knowledge of the fundamental niche of oysters in relation to biotic and abiotic conditions helps define the area where ecosystem engineers grow and survive well, and where their structures are likely to persist and be effective for coastal protection. Response curves of different life-history stages (larvae, juveniles and adults) of the Pacific oyster (Crassostrea gigas) were investigated along a tidal emersion gradient in a manipulative field study. Density of juvenile oysters was maximal around $36 \%$ tidal emersion. Shell growth of juveniles and adults, Condition Index of adults, and mortality of adults were negatively related to tidal emersion, whereas mortality of juveniles was positively related to tidal emersion. Tidal emersion had a strong effect on oyster survival and growth, with the most favourable being around $20-40 \%$ tidal emersion, as indicated by recruit density and Condition Index of adults. These findings suggest that the area of $20-40 \%$ tidal emersion is optimal for reef development, which is in line with other investigations of $C$. gigas and the eastern oyster C. virginica across different systems, supporting a broader geographical application of these findings.
\end{abstract}

Key words: oyster reef, ecosystem engineering, recruitment, growth, niche, ecosystem-based management, tidal flats 


\section{Introduction}

Marine habitats, such as oyster reefs, mangroves and salt marshes are recognized for their ecological engineering potential for coastal adaptation and hazard mitigation, as they have the natural capacity to reduce flow and dampen wave energy through their physical structures, and can keep pace with sea-level rise by natural accretion (Gutiérrez et al. 2011, Cheong et al. 2013, Duarte et al. 2013, Temmerman et al. 2013, Walles et al. 2014). Structure-forming aggregations of bivalves, such as oyster reefs and mussel beds, deliver many ecosystem services in marine and estuarine ecosystems (Grabowski \& Peterson 2007, Grabowski et al. 2012). In intertidal softsediment environments, mussel beds and oyster reefs commonly provide hard bottom substrate (Diederich 2005) essential for many structure-dependent organisms and complex food webs (Tolley \& Volety 2005, Scyphers et al. 2011, Spalding et al. 2014), and which offer protection against predation, waves, sedimentation and desiccation for many species (Gutiérrez et al. 2003, Commito et al. 2008). These structures alter water flow and reduce wave action (Borsje et al. 2011, Donker et al. 2013), while trapping and stabilizing sediment (van Leeuwen et al. 2010, Walles et al. 2014). Bivalve reefs and beds are therefore increasingly restored for shoreline protection and habitat enhancement (Byers et al. 2006), whose success depends on the long term persistence and sustainability of their structures.

Natural intertidal bivalve reefs do not occur randomly over tidal flats, nor do they cover the entire area. Local scale physical processes, food availability, competition and predation limit bivalve occurrence to a fraction of the total intertidal area (Heip et al. 1995). For example, in mussel beds, self-organization generates spatial patterns at different spatial scales, resulting in small-scale netshaped patterns due to behavioural aggregation of individuals, and large-scale banded patterns due to the interplay of intraspecific facilitation and resource depletion (Liu et al. 2014).

Within estuarine environments, biotic and abiotic factors affect species demography and determine the functional and realized niche of species. Predation, diseases, hypoxia, salinity, hydrodynamics, food availability and tidal emersion gradients alter demographic rates, which influence the development and persistence of marine populations. The fundamental niche for a species along one dimension is often conceptualized as a single response curve, with an optimum and thresholds beyond which individuals cannot survive (Jackson et al. 2009). Response curves, however, may differ among life-history stages, with adults often having wider niches than juveniles (Jackson et al. 2009). For sessile organisms, such as oysters, successful establishment and survival of a reef will depend both on the response of larvae and juveniles, which are important for the influx of new individuals into the reef, and the response of adults which supply off-spring and, in the case of oysters, settlement substrate for the next generation (Schulte et al. 2009, Walles et al. 2015). Understanding the response of different life-history stages of species to environmental factors is critical in predicting how species occurrence might be altered in the future, especially under influence of climate change.

This study focuses on the reef forming Pacific oyster, Crassostrea gigas (Thunberg, 1793), in the Oosterschelde estuary of The Netherlands. In this estuary tidal flats are eroding and disappearing due to human induced changes (van Zanten \& Adriaanse 2008). These tidal flats not only provide foreshore protection by reducing wave energy to the dikes, they also provide foraging grounds for 
migrating water birds for which the Oosterschelde is of international importance. Crassostrea gigas reefs locally protect the tidal flats against erosion in the Oosterschelde estuary (Walles et al. 2014). To mitigate erosion, artificial reefs can be constructed where erosion is most severe to provide a stable structure and stimulate reef development (de Vries et al. 2007). As oysters are sessile organisms, reef development depends on recruitment events followed by growth and survival of juveniles and adults. Response curves of three life-history stages (larvae, juvenile and adults) were investigated along a tidal emersion gradient in a manipulative field study on two intertidal flats in the Oosterschelde estuary. Recruitment, growth, oyster performance, and survival were quantified to determine niches of the life-history stages. We hypothesized that adaptation of oysters to tidal emersion leads to differential responses of growth and survival for the various life stages. Knowledge on Pacific oyster response to tidal emersion at different life stages can help decouple the fundamental and realized niches, identify habitat features where reefs can develop, and potentially serve as a valuable predictive tool for management and restoration practices.

\section{Methods}

\section{Study area}

The Oosterschelde estuary, located in the southwest of The Netherlands, is a $351 \mathrm{~km}^{2}$ semidiurnal tidal basin with tidal flats $\left(118 \mathrm{~km}^{2}\right)$, artificial rocky shore habitats (dikes), deep gullies and shallow water areas. In response to a devastating flood in 1953, a storm surge barrier was constructed at the sea side (finished 1986), separating the estuary from the North Sea; in the same period the eastern part of the estuary was closed off by two compartmentalization dams. The basin area of the Oosterschelde, the tidal prism, the tidal range and the tidal currents decreased as a consequence of these measures. At present, the estuary has a mean tidal amplitude ranging from $2.47 \mathrm{~m}$ near the storm surge barrier to $2.98 \mathrm{~m}$ in the northern branch and $3.39 \mathrm{~m}$ at the southeast end (Nienhuis \& Smaal 1994). The maximum current velocity is about $1.0 \mathrm{~m} \mathrm{~s}^{-1}$. Salinity throughout the estuary is high, generally > 30 psu (Nienhuis \& Smaal 1994). Due to the reduction of tidal volume and flow, the Oosterschelde basin is presently not in morphological equilibrium and the oversized channels are in need of sediment. Sediment erodes from the tidal flats into the channels during storms, whereas tidal forces are too small to redistribute the sediment back to the tidal flats (Mulder \& Louters 1994); on average, a net erosion rate of $10 \mathrm{~mm}_{\text {year }}{ }^{-1}$ occurs on the tidal flats (Santinelli \& de Ronde 2012). Reduction in tidal flat area and elevation diminishes valuable habitats, impacting bird and seal populations. It also poses a threat to coastal defence as dikes become less protected from waves and currents with the loss of tidal flats and salt marshes. The scale of erosion currently encountered in the Oosterschelde, make this ecosystem a suitable model system to study ecosystem-based coastal defence methods to combat coastal erosion. 


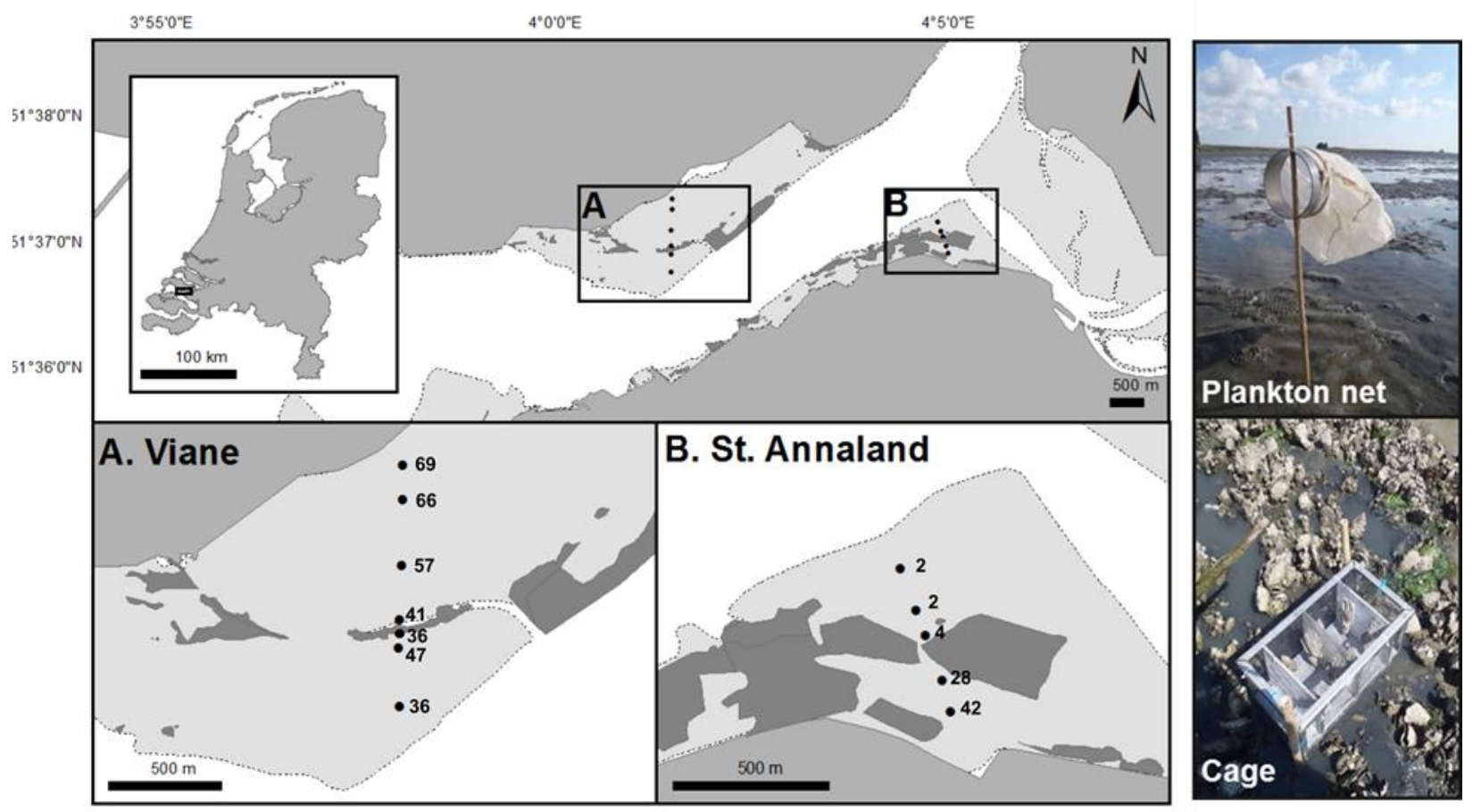

Fig. 1. Location of the two tidal flats (Viane and St. Annaland) in the Oosterschelde estuary (the Netherlands). Dotted lines (bordering light grey areas): mean low tide level. Light grey areas: intertidal zone. Dark grey areas: oyster coverage within the intertidal zone. Black dots: experimental sites with plankton nets and cages for the measurement of larvae occurrence, recruitment, growth rate, oyster performance and survival. Numbers: tidal emersion time in percentage. Star: hydraulic measure station Stavenisse.

\section{Realized niche of Pacific oyster Crassostrea gigas}

Crassostrea gigas was initially introduced in the Oosterschelde estuary in 1964, when the shellfish industry seeded the area with spat originating from British Columbia (Shatkin et al. 1997, Drinkwaard 1998, 1999). More introductions of both spat and adult oysters soon followed (Drinkwaard 1998). The first natural recruitment event after introduction was recorded in 1975 (Drinkwaard 1998). After this the oysters spread rapidly (Smaal et al. 2009), presently occupying $9 \mathrm{~km}^{2}$ of the intertidal (i.e. about $8 \%$ ) in the Oosterschelde, typically forming dense reefs. The realized niche of oyster reefs in the intertidal zone of the Oosterschelde was determined using intertidal Pacific oyster (C. gigas) reef mapping (van den Ende et al. 2014), in combination with bathymetry maps. Oyster maps of 1980, 1990, 2002, 2005 and 2011 were combined with bathymetry maps of 1983, 1990, 2001, 2007 and 2010, respectively.

\section{Site selection}

To investigate larval occurrence, recruitment, growth, oyster performance and survival along a tidal emersion gradient, a manipulative field experiment was conducted at two tidal flats (Viane and St. Annaland) in the northern branch of the Oosterschelde estuary (Fig. 1). Both tidal flats are connected to dikes, and contain natural oyster reefs and areas unoccupied by oysters between the dike and the natural reef and between the low water line and the natural reef. These flats differ in elevation and tidal emersion, with St. Annaland being lower than Viane. Several experimental sites 
were selected above mean low water covering a range of $2-69 \%$ tidal emersion, including 7 at Viane ranging from 36-69\% tidal emersion, and 5 at St. Annaland ranging from 2-42\% tidal emersion (Fig. 1). Tidal emersion time was calculated by converting height measurements of each experimental site into average percent of time the site was exposed between July and November 2010, using water levels measured at the gauge station Stavenisse (Fig. 1).

\section{Larval occurrence}

Pacific oysters spawn between July and September in the Oosterschelde estuary (Troost et al. 2009). The larvae stay approximately three weeks in the water column before they are competent to settle on a suitable substrate and metamorphose into the benthic juvenile stage (Troost 2010). As spawning occurs for several months, larval abundance and shell length were monitored daily from July 15 through August 10, 2010 to observe when oysters became competent to settle. At 5 locations along the platform of Wageningen IMARES (Yerseke, the Netherlands), samples of 20 $\mathrm{L}$ surface water were taken with a bucket (in total $100 \mathrm{~L}$ ), and filtered over a $100 \mu \mathrm{m}$ mesh. The residue was flushed into a bottle and brought to the lab. Samples were analysed on the same day. Bivalve larvae were counted using a universal camera microscope (Reichert Me-F2, 52.6x). Length of the larvae was measured as longest distance from anterior to posterior. In hatcheries, oyster larvae ready to settle have a length between 320 to $340 \mu \mathrm{m}$ (Helm \& Bourne 2004). When larvae of this size were observed in the samples (beginning of August 2010), plankton nets (Troost et al. 2009) were placed at each experimental site (Fig. 1) to investigate the occurrence of oyster larvae in the intertidal. The net opening $(10.0 \mathrm{~cm}$ diam; $60 \mu \mathrm{m}$ mesh size $)$ was oriented towards the current as nets could freely rotate around bamboo poles (Armonies 1994). Nets were placed during low tide, with the centre of the opening $30 \mathrm{~cm}$ above the sediment. Nets were deployed on two different dates at the two tidal flats (Viane: 11 August 2010; St. Annaland: 13 August 2010) and collected after two tidal cycles. Moist nets were transported in plastic bags to the laboratory, where their contents were flushed into plastic containers and fixed with lugol after which bivalve larvae were counted.

\section{Recruitment}

Three cages were placed at each experimental site from July 2010 until March 2011. Each cage (40 cm length $x 22 \mathrm{~cm}$ width $\mathrm{x} 24 \mathrm{~cm}$ height) was constructed of stainless steel covered by $5 \mathrm{~mm}$ plastic mesh (Fig. 1). Each cage enclosed 2 vertical settlement plates made from Plexiglas $(20 \times 18 \mathrm{~cm})$, roughened by sandblasting and covered with a thin layer of chalk. As settlement plates were in the field from the beginning of July, macroalgae were growing on the plates at the beginning of August, when larval settlement started. To standardized all plates to have an equal starting condition and a defined period in which a new biofilm could develop we scraped all plates clean in early August. Settlement of juvenile oysters (spat) was monitored monthly until the end of November. All live spat $>1 \mathrm{~mm}$ in shell length were counted. From each settlement plate pictures were taken to measure individual shell length (measured as longest distance from anterior to posterior, parallel to the hinge) and individual growth rate. Pictures were georeferenced in ArcGIS, after which the length of individual spat could be measured to the nearest $\mathrm{mm}$. To investigate winter mortality, cages 
were left in the field until March, when cages were brought to the lab where all live spat were counted and measured.

\section{Growth, condition index and mortality of adult oysters}

Cages also contained 16 wild-cultured oysters to investigate growth rate and oyster performance of adults. The wild-cultured oysters (C. gigas, 4 years old, $76 \pm 11 \mathrm{~mm}$ (mean $\pm \mathrm{sd}$ ) shell length) were collected from bottom culture plots at the Yerseke Bank in the Oosterschelde. Growth was measured as shell length and width increment between the start and end of the experiment, from early July through November 2010. At the end of the experiment, survivors at each tidal emersion level were cleaned free of encrusting organisms and brought to the laboratory to determine their condition index (CI). Initial condition of the wild-cultured oysters was obtained using 100 oysters at the start of the experiment. Condition index was calculated as:

Condition index $(\mathrm{g} / \mathrm{ml})=A F D W / I C V$

(Lawrence \& Scott 1982)

in which $A F D W$ is the ash-free dry weight in $\mathrm{g}$ and $I C V$ the internal cavity volume in $\mathrm{ml}$. The oysters were dissected, separating the tissue from the shell, after which the flesh was dried at $70^{\circ} \mathrm{C}$ until weight constancy was achieved ( $4 \mathrm{~d}$ ). Subsequently they were incinerated at $540^{\circ} \mathrm{C}$ for $4 \mathrm{~h}$ to determine their ash-free dry weight. Internal cavity volume was determined by submerging the empty oyster shell in water, pushing the two valves tightly together, creating a water-retaining oyster shell. The weight of the water in grams corresponds with the internal cavity volume of the oyster in millilitres. During the monthly visits, the number of dead oysters per cage was recorded and the dead oysters removed. Mortality was estimated as follows:

$M\left(\operatorname{day}^{-1}\right)=-1 / t \ln \left(N_{\mathrm{t}} / N_{0}\right)$

in which $N_{0}$ is the number of live oysters at the start of the experiment $\left(t_{0}\right)$ and $N_{t}$ the number of live oysters at time $t$. The total time of the experiment $(t)$ was $146 \mathrm{~d}$.

\section{Statistical analyses}

Patterns in larval occurrence, number of recruits, shell length of recruits, shell growth, condition index and survival along the tidal emersion gradient were examined using linear, polynomial and exponential regression. Trends were tested for data from both tidal flats combined, covering a range of 2-69\% tidal emersion. All analyses were performed using the SPSS statistical software version 21. Statistical significance was set at $\alpha=0.05$. 


\section{Results}

\section{Realized niche}

Whereas individual oysters can occur over the whole tidal emersion gradient, the occurrence of reefs on tidal flats was limited to areas experiencing $<60 \%$ tidal emersion in the Oosterschelde estuary (Fig. 2). The upper limits varied little during the 4 time periods from $<55-60 \%$. The extent of reef coverage increased substantially from 1980 to 2011, with most of the oyster reef area occurring at $<25 \%$ tidal emersion in the last 2 decades (Fig. 2).

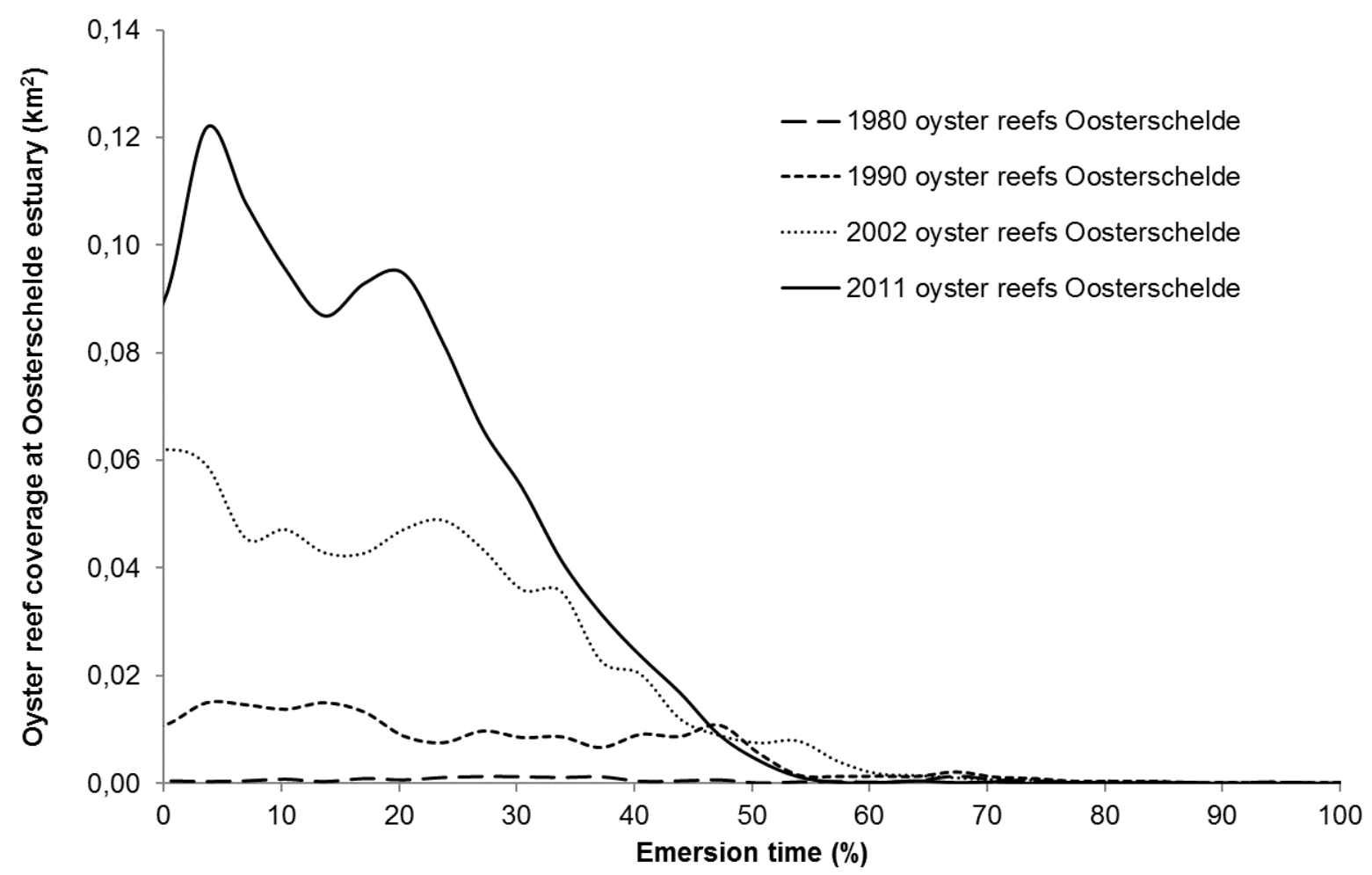

Fig. 2. Oyster reef coverage $\left(\mathrm{km}^{2}\right)$ along the tidal emersion gradient in the Oosterschelde estuary (The Netherlands).

\section{Larval occurrence}

Larvae competent to settle (length $>320 \mu \mathrm{m}$ ) were observed in the beginning of August. Larvae were present along the full tidal emersion gradient at the two study areas, but with high variability (Table 1) and no pattern (linear regression: $F_{1,10}=6.1, \mathrm{R}^{2}=-0.09, \mathrm{p}=0.781$ ).

\section{Recruitment}

Density of juvenile oysters was maximal around $36 \%$ tidal emersion with no juveniles at $69 \%$ tidal emersion (Table 1). Recruitment occurred from August through November, but subsequent mortality of settled oysters resulted in varying numbers of live oysters on the settlement plates (Table 1).

Shell length $(\mathrm{mm})$ and growth rates $\left(\mathrm{mm} \mathrm{d}^{-1}\right.$, Fig. 3) were significantly and negatively correlated with tidal emersion (Fig. 4) during all months (Table 2, Fig. S1). Juveniles at 69\% tidal emersion 
did not grow between August and March, whereas juveniles located below $42 \%$ emersion time doubled in length during the first month. In November juveniles reached a maximum size of 56 $\mathrm{mm}$ and $43 \mathrm{~mm}$ at St. Annaland and Viane, respectively. Winter mortality was significantly positively related with tidal emersion (exponential regression: $\mathrm{F}_{1,10}=6.1, \mathrm{R}^{2}=0.38, p=0.034$, mortality $=5.827 \mathrm{e}^{0.034 \text { tidal emersion }} ;$ Figure 5).

Table 1 Number of larvae collected per plankton net after two tidal cycles and live Crassostrea gigas recruits $\mathrm{m}^{-2}$ (mean \pm sd) per month observed on settlement plates in cages, located at two tidal flats (Viane and St. Annaland). Data are ordered by tidal emersion, which differs from the order of the experimental sites from mean low water line towards the dikes, see Fig. 1.

\begin{tabular}{|c|c|c|c|c|c|c|}
\hline \multirow[t]{2}{*}{ Location } & \multirow{2}{*}{$\begin{array}{c}\text { Tidal } \\
\text { emersion } \\
(\%)\end{array}$} & \multirow{2}{*}{$\begin{array}{c}\begin{array}{c}\text { Number of } \\
\text { C. gigas larvae per } \\
\text { plankton net }\end{array} \\
\text { larvae }\end{array}$} & \multicolumn{4}{|c|}{$\begin{array}{c}\text { Number of } \\
\text { C. gigas recruits } \mathbf{m}^{-2}\end{array}$} \\
\hline & & & August & September & October & November \\
\hline \multirow{5}{*}{$\begin{array}{l}\text { St. } \\
\text { Annaland }\end{array}$} & 2 & 2415 & * & $*$ & $88 \pm 21$ & $79 \pm 32$ \\
\hline & 2 & 23251 & $162 \pm 143$ & $194 \pm 114$ & $181 \pm 137$ & $130 \pm 72$ \\
\hline & 4 & 2083 & $245 \pm 255$ & $250 \pm 204$ & $241 \pm 164$ & $269 \pm 197$ \\
\hline & 28 & 12232 & $227 \pm 166$ & $181 \pm 155$ & $194 \pm 169$ & $190 \pm 179$ \\
\hline & 42 & 7153 & $116 \pm 32$ & $42 \pm 29$ & $65 \pm 67$ & $37 \pm 14$ \\
\hline \multirow{7}{*}{ Viane } & 36 & 0 & $597 \pm 350$ & $532 \pm 326$ & $394 \pm 227$ & $551 \pm 355$ \\
\hline & 36 & 7235 & $134 \pm 117$ & $755 \pm 649$ & $301 \pm 158$ & $310 \pm 197$ \\
\hline & 41 & 6309 & $56 \pm 63$ & $60 \pm 112$ & $32 \pm 51$ & $51 \pm 90$ \\
\hline & 47 & 6157 & $5 \pm 11$ & $65 \pm 123$ & $60 \pm 112$ & $65 \pm 133$ \\
\hline & 57 & 23553 & $5 \pm 11$ & 0 & $14 \pm 15$ & $19 \pm 23$ \\
\hline & 66 & 14486 & 0 & $56 \pm 110$ & $51 \pm 11$ & $56 \pm 123$ \\
\hline & 69 & 3899 & 0 & 0 & 0 & 0 \\
\hline
\end{tabular}

* Cages inaccessible
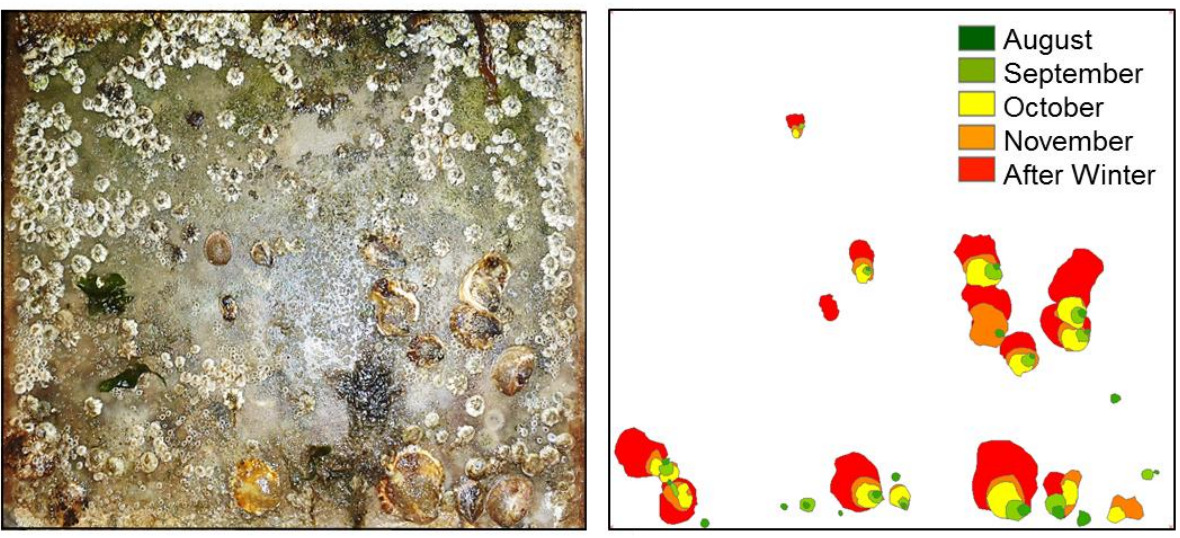

Fig. 3. Left: settlement plate (located at $36 \%$ tidal emersion near the existing reef at Viane) with oyster spat photographed after cages were brought back to the lab in early spring. Right: individual growth (indicated by the different colours) obtained from the monthly analysis of the photographed settlement plates. As temperatures already rose in March oyster spat started to grow after winter. 


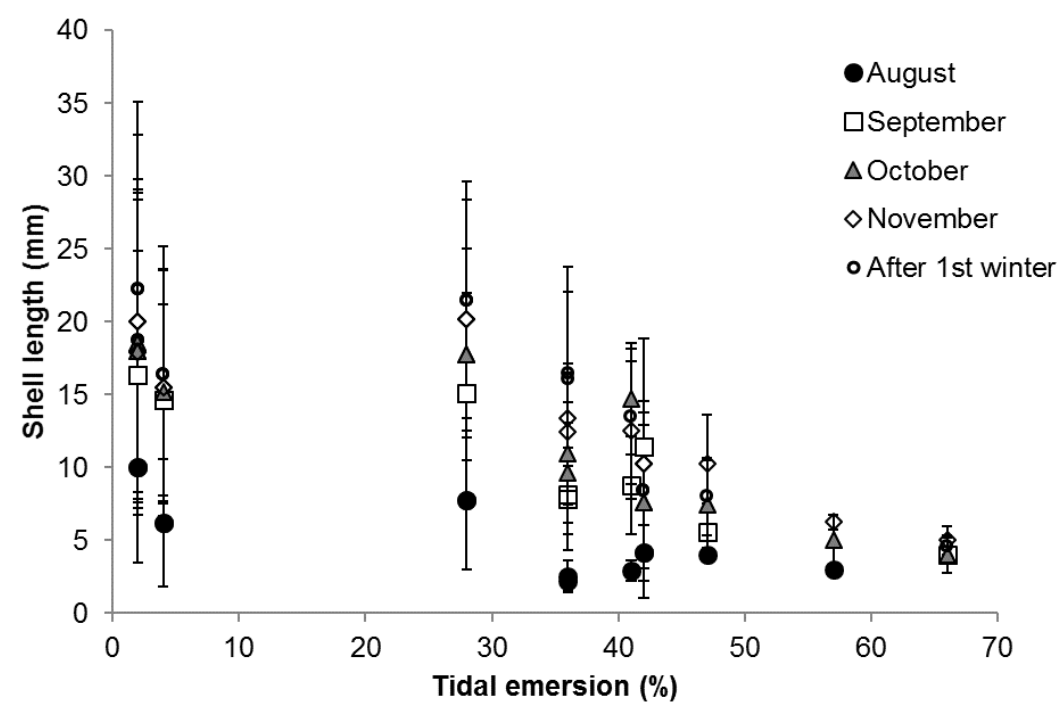

Fig. 4. Shell length (mean $\pm \mathrm{se}$ ) of $C$. gigas recruits in $\mathrm{mm}$ along a tidal emersion gradient at monthly intervals.

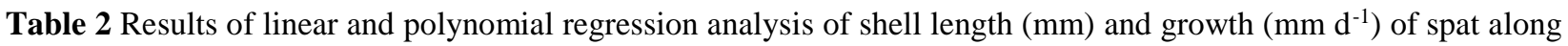
a tidal emersion gradient $(\mathrm{x})$ at monthly intervals.

\begin{tabular}{llllllllll}
\hline Dependent & Time & Constant & $\mathrm{x}$ & $\mathrm{x}^{2}$ & $\mathrm{x}^{3}$ & $\mathrm{R}^{2}$ & $d f$ & $\mathrm{~F}$ & $p$ \\
\hline Shell length $(\mathrm{mm})$ & August & 8.231 & -0.114 & & & 0.55 & 9 & 10.8 & 0.009 \\
& September & 13.992 & 0.089 & -0.009 & $7.0 \mathrm{E}-5$ & 0.86 & 3,6 & 12.1 & 0.006 \\
& October & 15.689 & 0.238 & -0.014 & 0.000 & 0.80 & 3,8 & 10.7 & 0.004 \\
& November & 17.562 & 0.136 & -0.008 & $4.6 \mathrm{E}-5$ & 0.85 & 3,8 & 15.1 & 0.001 \\
\hline Growth $\left(\mathrm{mm} \mathrm{d}^{-1}\right)$ & August & 0.276 & -0.004 & & & 0.55 & 8 & 9.9 & 0.014 \\
& September & 0.312 & -0.005 & & & 0.52 & 7 & 7.7 & 0.027 \\
& October & 0.149 & 0.001 & $-7.8 \mathrm{E}-5$ & $4.2 \mathrm{E}-7$ & 0.77 & 3,7 & 7.7 & 0.013 \\
& November & & & & & 0.15 & 11 & 1.9 & 0.198 \\
\hline
\end{tabular}

\section{Growth, condition index and mortality of adult oysters}

Shell length and width increment were negatively related with tidal emersion (Table 3, Fig. S2). Wild-cultured oysters had an average AFDW of $0.72 \pm 0.24 \mathrm{~g}$ (mean $\pm \mathrm{sd}$ ), ICV of $14.8 \pm 4.9 \mathrm{ml}$ (mean $\pm \mathrm{sd}$ ) and CI of $49.9 \pm 13.0 \mathrm{~g} \mathrm{ml}^{-1}$ (mean $\pm \mathrm{sd}$ ) in July. In November CI was negatively related with tidal emersion, with an optimum around $20 \%$ tidal emersion. CI increased at areas experiencing $<50 \%$ tidal emersion, whereas CI decreased at areas $>50 \%$ tidal emersion. AFDW and ICV were also negatively related with tidal emersion (Table 3, Fig. S2). Increase in ICV corresponded with shell length and width increment along the tidal emersion gradient.

Daily instantaneous mortality rate $\left(\mathrm{M} ; \mathrm{d}^{-1}\right)$ was $0.0022 \pm 0.0018 \mathrm{~d}^{-1}$ (mean $\pm \mathrm{sd}$ ) between July and November. Mortality also negatively relates with tidal emersion (Table 3, Fig. S2), with highest mortality (56\%) among oysters located at $2 \%$ tidal emersion. 
Table 3 Results of linear and polynomial regression analysis of shell growth, changes in oyster performance and mortality of adult oysters along a tidal emersion gradient $(\mathrm{x})$ for cages located on bare sediment.

\begin{tabular}{lllllllll}
\hline Dependent & Constant & $\mathrm{x}$ & $\mathrm{x}^{2}$ & $\mathrm{x}^{3}$ & $\mathrm{R}^{2}$ & $d f$ & $\mathrm{~F}$ & $P$ \\
\hline Shell length & 20.499 & -0.121 & & & 0.41 & 10 & 6.9 & 0.025 \\
Shell width & 14.564 & -0.214 & 0.005 & $-6.2 \mathrm{E}-5$ & 0.75 & 3,8 & 7.9 & 0.009 \\
ICV & 16.148 & -0.073 & 0.000 & $-8.2 \mathrm{E}-6$ & 0.72 & 3,8 & 7.1 & 0.012 \\
AFDW & 1.163 & -0.008 & 0.000 & $-6.2 \mathrm{E}-6$ & 0.89 & 3,8 & 21.7 & $<0.001$ \\
CI & 12.871 & -0.610 & 0.028 & 0.000 & 0.82 & 3,8 & 11.8 & 0.003 \\
Mortality & 54.517 & -1.506 & 0.020 & 0.000 & 0.90 & 3,8 & 32.3 & $<0.001$ \\
\hline
\end{tabular}

\section{Discussion}

Response curves of three life-history stages (larvae, juvenile and adults) were investigated along a tidal emersion gradient to identify the fundamental niche of the Pacific oyster (Crassostrea gigas). Tidal emersion had a strong effect on oyster recruitment, survival and growth, with the most favourable conditions around $20-40 \%$ tidal emersion, as indicated by recruit density and Condition Index of adults.

\section{Larval niche}

Larval abundance in the water column varied considerably over the tidal emersion gradient without any significant trend. In a well-mixed system with high residence time and small salinity changes, like the Oosterschelde estuary (Nienhuis \& Smaal 1994), larvae will be well dispersed throughout the water column (Troost 2010).

\section{Juvenile niche}

The juvenile niche was upper limited by tidal emersion time with an optimum around $36 \%$ tidal emersion. No juveniles survived at $69 \%$ tidal emersion, whereas larvae were present. Absence of juveniles does not imply a lack of recruitment as post-settlement mortality could have been responsible for the lack of juveniles. Oysters settling high in the intertidal zone experience physical stress caused by limited inundation (Rodriguez et al. 2014) or high temperatures, which could have caused the decline of juvenile densities in areas with long emersion times. A decline in juvenile densities in areas with low emersion times could have been due to predation. Fodrie et al. (2014) observed variable recruitment of the eastern oyster (Crassostrea virginica) along an emersion gradient with highest numbers in the subtidal; however, due to predation pressure in the subtidal subsequent survival was highest in the low and mid intertidal. In the Oosterschelde, adults experience minor predation pressure by birds in the high intertidal, whereas in the subtidal predation mainly affects juvenile (Troost 2010). The cages did not provide protection against predators smaller than the mesh size $(5 \mathrm{~mm})$ of the cages, such as shrimp (Beukema et al. 1998), as shrimps and crabs were observed within the cages. These predators could already have affected spatial variation before the juveniles reached a detectable size $>1 \mathrm{~mm}$. This could explain the decline of density in areas with shorter emersion times, as in C. virginica (Fodrie et al. 2014). 


\section{Adult niche}

Adult Pacific oysters had an optimum CI around 20\% tidal emersion, in line with observations by Ridge et al. (2015) for C. virginica. Above 40-50\% tidal emersion CI decreased, which is in line with the lack of growth by $C$. gigas around $36 \%$ emersion time at Menai Straits and $47 \%$ at R. Roach in England (Spencer et al. 1978). Although the CI decreased with increasing tidal emersion and declined compared to the initial condition when located above 50\% tidal emersion, oysters still grew above 50\% tidal emersion. Both shell growth and changes in meat content were negatively correlated with tidal emersion, as also observed by Spencer et al. (1978). The lower shell growth and meat content at long emersion times indicate that oysters had adapted to the physical stress of tidal emersion by reallocating energy away from growth, which widens the realized niche of adult oysters.

Mortality increased at experimental sites with short emersion times, whereas shell growth rates where highest there. In $C$. virginica, subtidally grown oysters dedicate a significant part of their energy to shell growth compared to intertidal oysters (Johnson and Smee 2014). This could be a response to predators as oysters increase shell growth in their presence (Newell et al. 2007). Energy used for shell growth results in lower tissue growth in bivalves, affecting their overall health (CI). In this study, both tissue growth and shell growth were negatively correlated with tidal emersion, which was most likely due to increased feeding time due to longer periods of inundation (Ingle \& Dawson 1952, Bishop \& Peterson 2006). Increase in both parameters did not occur at the same rate, leading to a parabolic trend for CI, indicating allocation of energy to shell growth. The greater amount of shell growth of the oysters in the low intertidal suggests a greater abundance of predators in this area, which is consistent with our mortality results. Unfortunately, knowledge about predation pressure on oysters is largely missing for our study area.
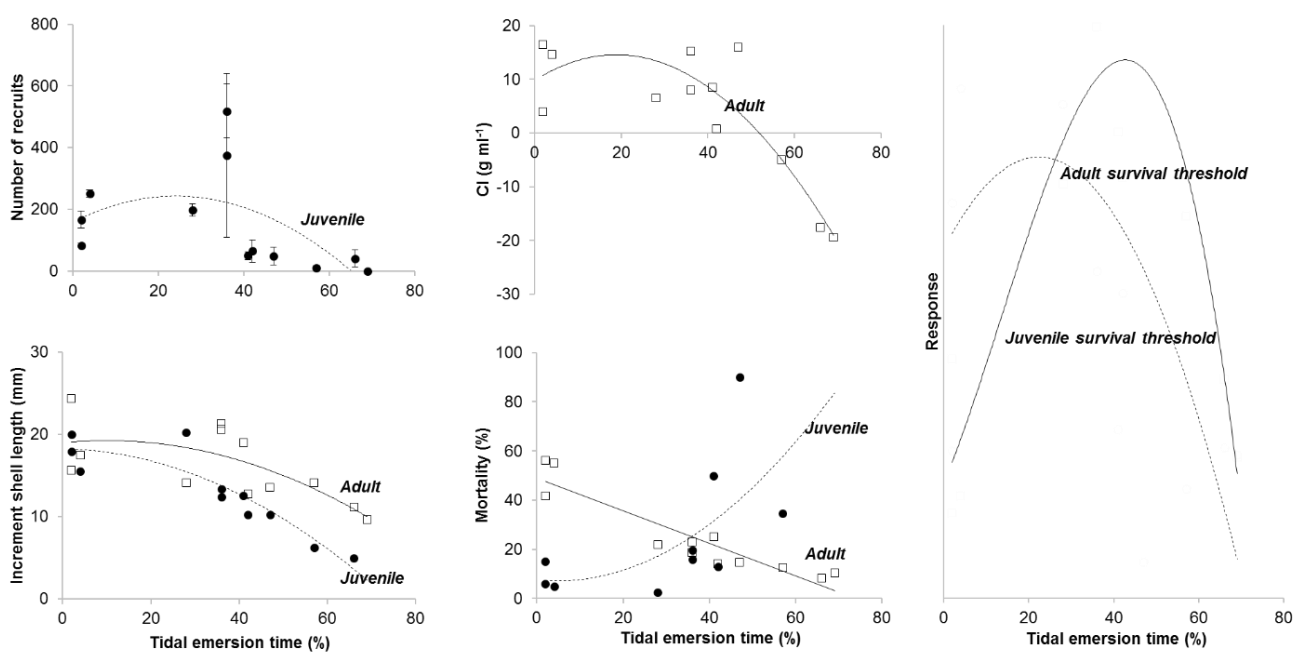

Fig. 5. Summary of the observed response curves of juvenile and adult oysters along a tidal emersion gradient. The number of juvenile oysters showed an optimum around 36\% tidal emersion. Shell growth $(\mathrm{mm})$ of both juvenile and adult oysters, changes in $\mathrm{CI}\left(\mathrm{g} \mathrm{ml}^{-1}\right)$ of adult oysters as well as mortality (\%) among adult oysters is negatively related with tidal emersion (\%). Mortality (\%) among juvenile oysters is positively related to tidal emersion (\%). Overall, adult and juvenile oysters differ in their response to the same response variable. 


\section{Implications for reef development}

Knowledge on the fundamental niche of the different life-history stages helps to define the realized niche occupied by oysters. Whereas oysters can occur over the whole tidal emersion gradient, reefs are upper limited to 55-60\% tidal emersion time. Failure in one life-history stage can form a bottleneck for reef development. Larval supply seems not to be limited in well-mixed systems like the Oosterschelde. The juvenile stage (i.e. spat) is limited by tidal emersion, with reduced recruitment success and growth rates with increasing tidal emersion. The adult stage is also limited by tidal emersion, as shell length increment and CI are negatively related with tidal emersion. Adult oysters are however able to adapt to the physical stress of tidal emersion by reallocating energy away from growth, and thereby widen the realized niche. Furthermore, mortality of adult oysters is positively correlated with tidal emersion, whereas mortality among the juveniles is negatively correlated. These results complement previous findings for $C$. virginica (Fodrie et al. 2014). Adult oysters have low mortality in the high intertidal zone, but due to the lack of sufficient recruitment, reefs will not develop except sporadically oysters on debris (pers. observ.). Based on the demographic response (recruitment, growth rate and oyster performance) to tidal emersion, it can be concluded that $C$. gigas reefs mainly develop in the low and mid (20-40\%) intertidal. As individual oyster growth contributes to overall reef growth (Walles et al. 2015), tidal emersion is also expected to effect the growth of the reef (Walles et al. 2016a). Walles et al. (2016b) showed that tidal emersion affected reef performance and had a structuring effect on the demographic responses at the reef scale. The fundamental niche helps to predict where ecosystem engineering oyster reefs can develop and form persistent structures which can be implemented in coastal defence schemes. Offering stable substrate in the form of artificial reefs could stimulate reef development at such locations (Walles et al. (2016b).

In summary, knowledge on the fundamental niche of different life-history stages defined the thresholds for establishment and reef development of the Pacific oyster C. gigas, and enhanced a mechanistic understanding of the distribution of these ecosystem engineers in space and time. Tidal emersion had a strong effect on oyster survival and growth, with the most favourable conditions being around 20-40\% tidal emersion. This is in line with Ridge et al. (2015) who observed optimal growth for individual oysters and whole reefs between 20 and $40 \%$ tidal emersion time. As studies on both $C$. gigas and $C$. virginica across different systems complement each other, the observed trends in relation to tidal emersion time have a broad geographical application.

\section{Acknowledgements}

The work presented in this paper was carried out as part of the innovation programme, Building with Nature, which is funded from several sources, including the Subsidieregeling Innovatieketen Water (Staatscourant no. 953 and 17009), sponsored by the Dutch Ministry of Transport, Public Works, and Water Management, and partner contributions by the participants of the EcoShape Foundation. EcoShape receives co-funding from the European Fund for Regional Development and the municipality of Dordrecht. Thanks to Aard Cornelissen for providing the wild-cultured 
Differing niche dimensions in Pacific oysters

oysters. Thanks to Agathe Douabin for assistance in the field and the larval monitoring. We thank anonymous reviewers and the editor for their helpful comments.

\section{References}

Armonies W (1994) Drifting meio- and macrobenthic invertebrates on tidal flats in Königshafen: A review. Helgol Mar Res 48:299-320

Beukema JJ, Honkoop PJC, Dekker R (1998) Recruitment in Macoma balthica after mild and cold winters and its possible control by egg production and shrimp predation. Hydrobiologia 375-376:23-34

Bishop MJ, Peterson CH (2006) Direct effects of physical stress can be counteracted by indirect benefits: oyster growth on a tidal elevation gradient. Oecologia 147:426-433

Borsje BW, van Wesenbeeck BK, Dekker F, Paalvast P, Bouma TJ, van Katwijk MM, de Vries MB (2011) How ecological engineering can serve in coastal protection. Ecol Eng 37:113-122

Byers JE, Cuddington K, Jones CG, Talley TS, Hastings A, Lambrinos JG, Crooks JA, Wilson WG (2006) Using ecosystem engineers to restore ecological systems. Trends Ecol Evol 21:493-500

Cheong SM, Silliman B, Wong PP, van Wesenbeeck B, Kim CK, Guannel G (2013) Coastal adaptation with ecological engineering. Nat Clim Change 3:787-791

Commito JA, Como S, Grupe BM, Dow WE (2008) Species diversity in the soft-bottom intertidal zone: Biogenic structure, sediment, and macrofauna across mussel bed spatial scales. J Exp Mar Biol Ecol 366:70-81

de Vries MB, Bouma TJ, van Katwijk MM, Borsje BW, van Wesenbeeck B (2007) Biobouwers van de kust. Delft Hydraulics, Delft, the Netherlands

Diederich S (2005) Differential recruitment of introduced Pacific oysters and native mussels at the North Sea coast: coexistence possible? J Sea Res 53:269-281

Donker JJA, van der Vegt M, Hoekstra P (2013) Wave forcing over an intertidal mussel bed. J Sea Res 82:54-66

Drinkwaard AC (1998) Introductions and developments of oysters in the North Sea area: a review. Helgol Meeresunters 52:301-308

Drinkwaard AC (1999) History of cupped oyster in european coastal waters. Aquacult Eur 15:7-14

Duarte CM, Losada IJ, Hendriks IE, Mazarrasa I, Marba N (2013) The role of coastal plant communities for climate change mitigation and adaptation. Nat Clim Change 3:961-968

Fodrie FJ, Rodriguez AB, Baillie CJ, Brodeur MC, Coleman SE, Gittman RK, Keller DA, Kenworthy MD, Poray AK, Ridge JT, Theuerkauf EJ, Lindquist NL (2014) Classic paradigms in a novel environment: inserting food web and productivity lessons from rocky shores and saltmarshes into biogenic reef restoration. J Appl Ecol 51:1314-1325

Grabowski JH, Brumbaugh RD, Conrad RF, Keeler AG, Opaluch JJ, Peterson CH, Piehler MF, Powers SP, Smyth AR (2012) Economic valuation of ecosystem services provided by oyster reefs. BioScience 62:900-909

Grabowski JH, Peterson CH (2007) Restoring oyster reefs to recover ecosystem services. In: Cuddington K, Byers JE, Wilson WG, Hastings A (eds) Ecosystem Engineers: Plants to Protists. Elsevier

Gutiérrez JL, Clive GJ, David LS, Oscar OI (2003) Mollusks as ecosystem engineers: the role of shell production in aquatic habitats. Oikos 101:79-90

Gutiérrez JL, Jones CG, Byers JE, Arkema KK, Berkenbusch K, Committo JA, Duarte CM, Hacker SD, Hendriks IE, Hogarth PJ, Lambrinos JG, Palomo MG, Wild C (2011) Physical ecosystem engineers and the functioning of estuaries and coasts. In: Wolanski E, McLusky D (eds) Treatise on estuarine and coastal science. Elsevier, Amsterdam, The Netherlands

Heip CHR, Goosen NK, Herman PMJ, Kromkamp J, Middelburg JJ, Soetaert K (1995) Production and consumption of biological particles in temperate tidal estuaries. Oceanogr Mar Biol Annu Rev 33:1-149

Helm MM, Bourne N (2004) The hatchery culture of bivalves: a practical manual. Food and Agriculture Organization of the United Nations, Rome

Ingle, Dawson (1952) Growth of the American Oyster, Crassostrea virginica (Gmelin) in Florida waters. Bull Mar Sci 2:393-404 
Jackson ST, Betancourt JL, Booth RK, Gray ST (2009) Ecology and the ratchet of events: Climate variability, niche dimensions, and species distributions. Proc Natl Acad Sci USA 106:19685-19692

Johnson KD, Smee DL (2014) Predators influence the tidal distribution of oysters (Crassostrea virginica). Mar Biol 161:1557-1564

Lawrence D, Scott G (1982) The determination and use of condition index of oysters. Estuar Coasts 5:23-27

Liu QX, Herman PMJ, Mooij WM, Huisman J, Scheffer M, Olff H, van de Koppel J (2014) Pattern formation at multiple spatial scales drives the resilience of mussel bed ecosystems. Nat Commun 5:5234

Mulder JPM, Louters T (1994) Changes in basin geomorphology after implementation of the Oosterschelde estuary project. Hydrobiologia 282-283:29-39

Newell R, Kennedy V, Shaw K (2007) Comparative vulnerability to predators, and induced defense responses, of eastern oysters Crassostrea virginica and non-native Crassostrea ariakensis oysters in Chesapeake Bay. Mar Biol 152:449-460

Nienhuis PH, Smaal AC (1994) Oosterschelde Estuary (The Netherlands): a case-study of a changing ecosystem. Kluwer Academic Publishers, Dordrecht, the Netherlands

Ridge JT, Rodriguez AB, Joel Fodrie F, Lindquist NL, Brodeur MC, Coleman SE, Grabowski JH, Theuerkauf EJ (2015) Maximizing oyster-reef growth supports green infrastructure with accelerating sea-level rise. Sci Rep 5:14785

Rodriguez AB, Fodrie FJ, Ridge JT, Lindquist NL, Theuerkauf EJ, Coleman SE, Grabowski JH, Brodeur MC, Gittman RK, Keller DA, Kenworthy MD (2014) Oyster reefs can outpace sea-level rise. Nat Clim Change 4:493-497

Santinelli G, de Ronde JG (2012) Volume analysis on RTK profiles of the Eastern Scheldt. Deltares, The Netherlands

Schulte DM, Burke RP, Lipcius RN (2009) Unprecedented restoration of a native oyster metapopulation. Science 325:1124-1128

Scyphers SB, Powers SP, Heck KL, Byron D (2011) Oyster reefs as natural breakwaters mitigate shoreline loss and facilitate fisheries. PLos ONE 6:e22396

Shatkin G, Shumway SE, Hawes R (1997) Considerations regarding the possible introduction of the Pacific oyster (Crassostrea gigas) to the Gulf of Maine: a review of global experience. J Shellfish Res 16:463-477

Smaal A, Kater B, Wijsman J (2009) Introduction, establishment and expansion of the Pacific oyster Crassostrea gigas in the Oosterschelde (SW Netherlands). Helgol Mar Res 63:75-83

Spalding MD, Ruffo S, Lacambra C, Meliane I, Hale LZ, Shepard CC, Beck MW (2014) The role of ecosystems in coastal protection: Adapting to climate change and coastal hazards. Ocean Coast Manage 90:50-57

Spencer BE, Key D, Millican PF, Thomas MJ (1978) The effect of intertidal exposure on the growth and survival of hatchery-reared Pacific oysters (Crassostrea gigas Thunberg) kept in trays during their first ongrowing season. Aquaculture 13:191-203

Temmerman S, Meire P, Bouma TJ, Herman PMJ, Ysebaert T, De Vriend HJ (2013) Ecosystem-based coastal defence in the face of global change. Nature 504:79-83

Tolley SG, Volety AK (2005) The role of oysters in habitat use of oyster reefs by resident fishes and decapod crestaceans. J Shellfish Res 24:1007-1012

Troost K (2010) Causes and effects of a highly successful marine invasion: Case-study of the introduced Pacific oyster Crassostrea gigas in continental NW European estuaries. J Sea Res 64:145-165

Troost K, Gelderman E, Kamermans P, Smaal AC, Wolff WJ (2009) Effects of an increasing filter feeder stock on larval abundance in the Oosterschelde estuary (SW Netherlands). J Sea Res 61:153-164

van den Ende D, van Asch M, Brummelhuis EB, Troost K (2014) Japanse oesterbanken op droogvallende platen in de Nederlandse kustwateren in 2014: bestand en arealen. IMARES Wageningen UR, Yerseke, the Netherlands

van Leeuwen B, Augustijn DCM, van Wesenbeeck BK, Hulscher SJMH, de Vries MB (2010) Modeling the influence of a young mussel bed on fine sediment dynamics on an intertidal flat in the Wadden Sea. Ecol Eng 36:145153

van Zanten E, Adriaanse LA (2008) Verminderd getij. Verkenning naar mogelijke maatregelen om het verlies van platen, slikken en schorren in de Oosterschelde te beperken. Rijkswaterstaat, Middelburg, the Netherlands 
Walles B, Fodrie FJ, Nieuwhof S, Jewell OJD, Herman PMJ, Ysebaert T (2016a) Guidelines for evaluating performance of oyster habitat restoration should include tidal emersion: reply to Baggett et al. Restoration Ecology 24:4-7

Walles B, Mann R, Ysebaert T, Troost K, Herman PMJ, Smaal A (2015) Demography of the ecosystem engineer Crassostrea gigas, related to vertical reef accretion and reef persistence. Estuar Coast Shelf Sci 154:224-233

Walles B, Salvador de Paiva J, van Prooijen B, Ysebaert T, Smaal A (2014) The ecosystem engineer Crassostrea gigas affects tidal flat morphology beyond the boundary of their reef structures. Estuar Coasts 38:941-950

Walles B, Troost K, van den Ende D, Nieuwhof S, Smaal AC, Ysebaert T (2016b) From artificial structures to selfsustaining oyster reefs. J Sea Res 108:1-9 